\title{
Anal polyp caused by Schistosoma mansoni
}

\author{
Pedro Raso ${ }^{[1]}$, Eliane Mansur Sander ${ }^{[2]}$, Leonardo Arruda Moraes Raso ${ }^{[3]}$ \\ and José de Souza Andrade Filho ${ }^{[4]}$
}

[1]. Departamento de Anatomia Patológica e Medicina Legal, Faculdade de Medicina, Universidade Federal de Minas Gerais, Belo Horizonte, MG. [2]. Serviço de Proctologia, Hospital Felício Rocho, Belo Horizonte, MG. [3]. Departamento de Patologia, Faculdade de Medicina, Universidade Federal de Minas Gerais, Belo Horizonte, MG. [4]. Departamento de Patologia, Faculdade de Ciências Médicas de Minas Gerais, Belo Horizonte, MG.

\begin{abstract}
We describe a schistosomal polyp in the anus of a 24-year-old patient, born in Viçosa, State of Minas Gerais, and living in Belo Horizonte, State of Minas Gerais. From 8 to 13 years of age, he swam in the rivers that bathe Viçosa. The histopathological examination has shown a lesion, lined by a keratinized squamous epithelium, ulcerated, with granulomas, centered or not by Schistosoma mansoni egg, laid, in loco, by the female present in the vascular lumen of a vein of the hemorrhoidal plexus. There was also a diffuse, nonspecific inflammation in the dermis. The patient was treated with praziquantel. Four months after the treatment, sigmoidoscopy showed a normal rectal mucosa, and negative oogram and stool tests. Ultrasound of abdomen was normal.
\end{abstract}

Keywords: Schistosoma mansoni. Anal polyp. Anus. Schistosomiasis.

\section{INTRODUCTION}

Schistosomal polyps, although relatively rare, are more common among hyperplastic forms of schistosomiasis. Their preferential site is the rectum, being rare in the sigmoid and exceptional in the other parts of the large and small intestines. In most cases, they are multiple, reaching even hundreds of polyps. Their volume varies from the size of a rice grain to the size of a child's fist. They consist of a conjunctive-vascular axis where eggs and granulomas are found, whether just a few or plenty of them, lined by the epithelium. The conjunctivevascular neoformations which form the polyp excrescence are sometimes excessive regarding the number of eggs and the inflammatory reaction. In general, this is unspecific and almost always eosinophilic followed by other exudate cells. Worms were found sometimes alive, either isolated or mating and sometimes dead, with the characteristic tissue reaction ${ }^{1}$.

Complications were limited to small hemorrhages. However, there have been reports of rare cases of intestinal obstruction, with an invagination from the proximal to the distal portion, by a giant polyp located in the jejuno-ileal transition ${ }^{2}$, a large polyp mimicking a sigmoid ${ }^{3}$ or rectal ${ }^{4}$ tumor, with obstructive or hemorrhagic symptoms and a giant polyp with intussusception and exteriorization through the anus ${ }^{5}$.

A case of condyloma acuminatum positive for human papiloma virus (HPV) with Schistosoma mansoni eggs in

\footnotetext{
Address to: Prof. Pedro Raso. Rua Piaúi 1055/601, Bairro Funcionários, 30150-321 Belo Horizonte, MG, Brasil.

Phone: 5531 3223-8923

e-mail: pedroraso29@gmail.com

Received 24 June 2012

Accepted 18 September 2012
}

the lesion have been reported at the anal region of human imunudeficiency virus (HIV)-positive patient ${ }^{6}$ as well as an association of anal fissure and a giant polyp with multiple calcified ova of Shistossoma mansoni, in Cameroonian woman, HIV-positive, living in Germany ${ }^{7}$. Moreover, a case of Shistossomal colonic polyposis has been described in a Ugandan man with advanced HIV-1 disease ${ }^{8}$. The same association has also been observed in the uterine cervix.

The objective of our study was to report a case of anal polyp which was not associated with condyloma acuminatum in a patient with no history of HIV infection, caused by Schistosoma mansoni eggs. As far as we know, this is the first case in the Brazilian literature on a schistosomal polyp in the anus with these characteristics.

\section{CASE REPORT}

W.R.C. is a 24-year-old male patient, single, born in Viçosa, State of Minas Gerais and living in Belo Horizonte, State of Minas Gerais, Brazil, and works as a test driver. Some months earlier, he noticed a tumor formation with a slow and progressive growth in the anal region, followed by pain and intense pruritus, with no bleeding and no secretion. From 8 to 13 years of age, he repeatedly swam in rivers and streams in the region of Viçosa and noticing some itching afterwards. He has not complained of diarrhea or constipation. He still reports pruritus and pain after defecation, which are alleviated with the use of an ointment (as reported by the patient). His general health is good, and he is hydrated, afebrile, anicteric, acyanotic, not pale with no other significant date. His anal lesion was resected on the 09/12/2011 which was sent for an anatomopathological examination. The macroscopy has shown a polypoid lesion was lined by a white irregular skin, with an area of superficial ulceration, measuring $2.5 \times 1.2 \times 0.7 \mathrm{~cm}$, fixed in formaldehyde at $10 \%$. Section surface was whitish and firm. It was then divided 
in half and included in paraffin. Sections of $4 \mu$, stained with hematoxylin and eosin (HE) and with Gomori trichrome were examined using an optical microscope.

The histopathological study has shown a lesion lined by a squamous epithelium, with an area of ulceration. When the epithelium was intact, irregular basal zone hyperplasia, acanthosis and papillomatosis and edema of Malphigian layer were observed. In superficial areas of the epithelium, there are empty cavities or those filled with an amorphous, acidophilic substance, with several sizes and interspersed by cells with an increased volume, an acidophilic cytoplasm, nucleated or not (Figure 1A). Ulceration zone was represented by fibrinoid necrosis, consisting of fibrin, red blood cells, leukocytes and nucleus residues, on a layer of granulation tissue characterized by ectasic and congested vessels interspersed by fibrous connective and muscle bundles (Figure 1B). There is an intense chronic granulomatous inflammation in the dermis caused by schistosomiasis, characterized by the presence of several granulomas isolated or confluent, in several evolutionary stages, most of them in the exudative-productive stage, centered by Langhans or a foreign body type giant cells, comprising the egg or its residues.

The most recent granulomas had a central necrosis around the egg involved by a layer of epithelioid macrophages and, more externally, by a mixture of cells with the predominance of mononuclear cells and eosinophils (Figure 2A). Most of them did not have a concentric fibrosis, in onion drusens, which are characteristic of granulomas healing by fibrosis. The presence of a couple of adult worms was observed in the lumen of a dermal vein (Figure 2B). Both, mainly the female, had a schistosomal pigment (hemozoin), staining part of the body in black. The female has still had a great number of oocytes. Their presence allows us to assume that their posture occurred in loco and that the large number of eggs is due to successive postures.

In addition to the granulomatous inflammation, caused by the eggs, there was also another one, which was nonspecific and diffuse, consisting predominantly of mononuclear cells with a moderate amount of eosinophils, particularly intense in the superficial dermis and in the eroded area, involving vessels, nerves and muscular tissue and eggshells. A light hemorrhage was detected by well-preserved red blood cells in the interstitium.

In conclusion, chronic granulomatous inflammation caused by $S$. mansoni with polyp in the anus.

With the result of schistosomiasis, he was treated with six tablets of cestox, $600 \mathrm{mg}$ (praziquantel). He was then re-examined four months after the treatment, and was shown to have a good general health. Rectal mucosa was normal at retossigmoidoscopy; his oogram by rectal biopsy and parasitological stool exams were negative; his total abdominal ultrasound did not have any abnormalities; and intestinal, abdominal and neurological symptoms were absent. The presence of anal fistula was observed and it will be operated timely.

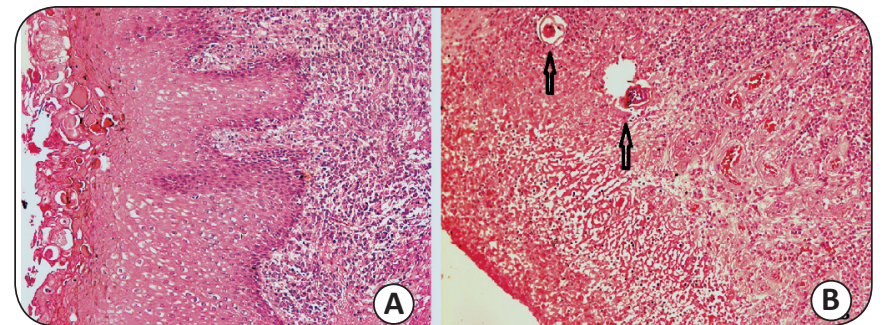

FIGURE 1 - A) Squamous epithelium with acanthosis, papillomatosis, basal cell hyperplasia, edema of the Malphigian layer and degeneration of superficial epithelial cells with the formation of cavities containing amorphous substance. HE X 300 B) Ulceration area. Tissue in fibrinoid necrosis, ectatic and congested vessels, marked nonspecific inflammatory infiltrate, with a predominance of eosinophils granulocytes and mononuclear cells, involving Schistosoma mansoni eggs (arrows). HE X 300.

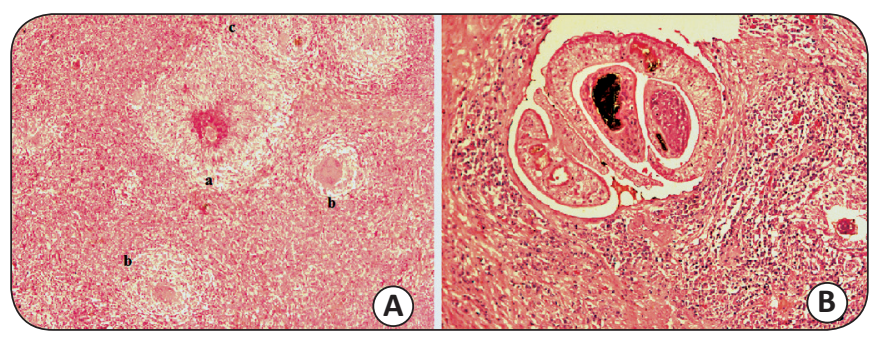

FIGURE 2 - A) Five granulomas: a) the largest in the necrotic-exudative phase, with necrosis around the egg involved by an aggregate of epithelioid histiocytes; b) to the right and below, centered by a foreign body giant cell, and on the top; c) Langhans cells. HE X 150. B) Couple of light worms in the vascular lumen. The female (the smaller) is hugged by the male, stained in black by the hemozoin pigment and with several oocytes. Marked infiltration of eosinophils and mononuclear cells around the egg. HE X 300.

\section{DIsCusSION}

We describe a case of schistosomal polyp in the anus, caused by Schistosoma mansoni, in a 24-year-old man, who was probably infected when he was a child (from 8 to 13 years of age), in rivers and streams in Viçosa State of Minas Gerais. Viçosa is bathed by Rio Turvo Sujo, which is an affluent of Rio Turvo Limpo, one of the rivers from the Rio Doce basin. Another important datum in the patient's history (whose last infecting bath took place when he was 13 years old) is the presence of a couple of live worms in the vascular lumen of a vein of the external hemorrhoidal plexus (Figure 2B), 11 years after the contact with the waters of Rio Turvo Sujo and its affluent, Córrego Cristal (Figure 3).

As far as we know, this is the first case of polyp resulting from a chronic granulomatous inflammation caused by $S$. mansoni eggs deposited in the anal region. The present case is different from the anal polyp described by Carneiro et al. ${ }^{5}$, as it is not associated with infections neither with HPV nor with HIV and from the giant anal polyp in a HIV-positive patient pointed out by Gohlan et al. .

Cutaneous involvement by Schistosoma haematobium occurred especially in the genital and perigenital regions where they start as assymptomatic papules which slowly 


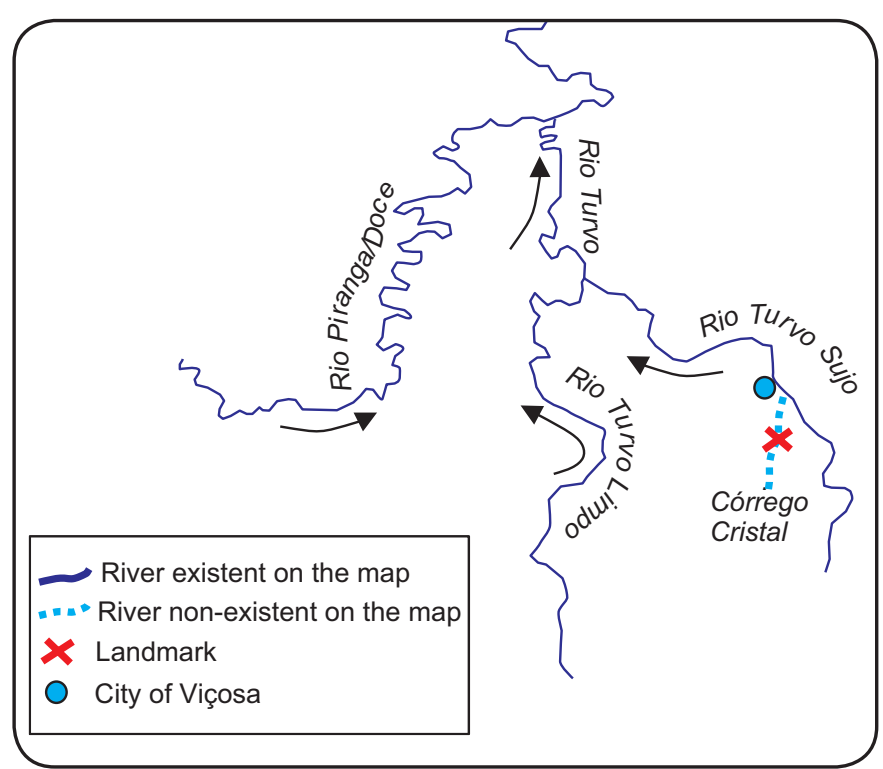

FIGURE 3 - Design of the Rivers, Turvo Limpo and Turvo Sujo.

become vegetative lesions ${ }^{9,10}$. Cutaneous schistosomiasis caused by S. mansoni, is rare, and is preferably located in the thorax and abdomen ${ }^{11,12}$. It may be associated with intestinal, hepatointestinal and hepatosplenic schistosomiasis or with neuroschistosomiasis. In our case, it is associated to the intestinal form. There were no signs and symptoms for the diagnosis of the hepatosplenic form or of neuroschistosomiasis.

Granulomatous reaction observed in this case is similar to that described in a pseudotumoral form of schistosomiasis mansoni ${ }^{13}$. Granulomas in several stages of evolution indicate oviposition in successive stages and that there was a modulation of the granulomatous reaction described in laboratory animals ${ }^{14}$ and in human beings ${ }^{15}$. Changes in the surface of the epithelium were interpreted as traumatic, and caused by the use of toilet paper after defecation.

The index of Shistossomal infestation is low in the region of Viçosa ${ }^{16}$.

\section{ACKNOWLEDGMENTS}

To Carolina Dias for the English version.

\section{REFERENCES}

1. Raso P, Bogliolo L. Patologia. In: Cunha AS, editor. Esquistossomose mansoni. São Paulo: Savier Editora da Universidade de São Paulo 1970; p. 77-130.

2. Bicalho AS, Souza RP. Pólipo esquistossomótico do intestino delgado. Hospital 1964; 66: 425-430.

3. Santana HJ, Lima CA. Pseudotumor esquistossomótico de cólon - relato de um caso. Rev Bras Coloproct 1985; 5:17-21.

4. Miranda LEC, Carvalho E, Lima DL. Giant schistosomal granuloma mimicking rectum neoplasia: case report. J Coloproctol 2011; 31: 1-3.

5. Carvalho RB, Sobral HAC, Lopes JM, Todinov LR, Formiga GJS. Granuloma esquistossomótico gigante do cólon com intussuscepção: Relato de caso. Rev Bras Coloproct 2008; 28: 347-349.

6. Carneiro FP, Moraes MAP, Carneiro MV, Maia LB, Magalhães AV. Condiloma acuminado anal com ovos de Schistosoma mansoni em paciente HIV-positivo. Rev Bras Coloproct 2007; 27:207-209.

7. Gholam P, Autschbach F, Hartschuh W. Shistosomiasis in an HIV-positive patient presenting as an anal fissure ang giant anal polyp. Arch Dematol 2008; 144:950-952.

8. Javid B, Alyu SH, Save VE, Carmichael AJ, Lever AML. Shistossomal colonic polyposis ia an HIV-positive man. AIDS 2007; 21:386-388.

9. El Mofty AM, Cahil KM. Cutaneous manifestations of schistosomiasis. Intern J Dermat 1964; 3:157-161.

10. Ramdial PK, Calonge E, Sing Y, Govender P. Extra-genital bilharziasis cutanea tarda. J Cutaneous Path 2009; 36:766-771.

11. Andrade Filho JS, Lopes MS, Corgozinho Filho AA, Pena GP. Ectopic cutaneous schistosomiasis report of two cases and a review of literature. Rev Inst Med Trop São Paulo 1996; 40:253-257.

12. Raso P, Alves CF, Tafuri A, Tafuri WL. Schistosomiasis mansoni in the sacral region. Dermatol 2010; 2:1-7.

13. Raso P, Raso LAM, Melo FA, Tafuri WL. Schistosoma mansoni granuloma in late evolutive phase, in a case of tumoral form in man. Rev Soc Bras Med Trop 2012; 45:627-632.

14. Andrade ZA, Warren KS. Mild prolonged schistosomiasis in mice: alterations in host response with time and the development of portal fibrosis. Trans R Soc Trop Med Hyg 1964; 58:53-57.

15. Raso P, Bernardes RC, Tafuri WL, Bogliolo L. As dimensões do granuloma causado pelos ovos de S. mansoni no fígado humano. Rev Soc Bras Med Trop 1976; 12:45-49.

16. Martins FT. Mapeamento do risco de esquistossomose no Estado de Minas Gerais usando dados ambientais e sociais. Dissertação de mestrado do curso de pós-graduação em Computação aplicada. Instituto Nacional de Pesquisas IMPE - São José dos Campos, SP - Brasil. 2009; 144p. 